\title{
Peningkatan Produksi dan Mutu Benih Jagung Hibrida melalui Aplikasi Pupuk N, P, K dan Bakteri Probiotik
}

\section{The Increased of Production and Quality of Hybrid Corn Seed through Application of N, P, K Fertilizer and Probiotic Bacteria}

\section{Putri Melia Sari, Memen Surahman* dan Candra Budiman}

\author{
Departemen Agronomi dan Hortikultura, Fakultas Pertanian, Institut Pertanian Bogor \\ (Bogor Agricultural University), Jalan Meranti, Kampus IPB Darmaga, Bogor 16680, Indonesia \\ Telp. \& Faks. 0251-8629353 e-mail: agronipb@indo.net.id \\ *Penulis untuk korespondensi : memensurahman@yahoo.co.id
}

Disetujui 20 Agustus 2018 / Published online 3 September 2018

\begin{abstract}
The research was conducted in Indonesia Center for Rice Research, Muara, Bogor and Seed of Technology Laboratory, Department of Agronomy and Horticulture, Faculty of Agriculture, Bogor Agricultural University from November 2016 to May 2017 using Randomized Complete Block Design $(R C B D)$ one factor and three replications. The factors used were the combination of $N, P, K$ and probiotic bacteria consisting of 15 treatment levels ie P1N1, P2N1, P3N1, P4N1, P5N1, P1N2, P2N2, P3N2, P4N2, $P 5 N 2, P 1 N 4, P 2 N 4, P 3 N 4, P 4 N 4$ and P5N4 with the information that N1 = control, $N 2=75 \mathrm{~kg} \mathrm{ha}-1$ Urea,

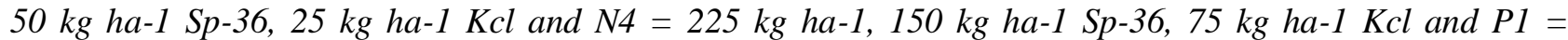
control, $P 2=P 24+A z L 7, P 3=P 24+A c C K W 5, P 4=P 24+A z L 7$ and P5 $=P 24+$ AcCKB20. Bacteria $P 24$ is a bacterium class Pseudomonas sp. as a solvent phosphate, AzL7 is a bacterium of the class of Azotobacter, AcCKB2O and AcCKW5 bacterium class Actinomycetes sp. as a nitrogen fixer. The results showed that the combination of $N, P, K$ and probiotic bacteria influenced plant height and leaf number of 2 , 4, 6 and 8 MST and influenced stem circumference 4, 6 and 8 MST. The combination of $N, P, K$ and probiotic bacteria also influenced the number of cobs of harvest, the weight of the earlob, the weight of the dry bean, the length of the ear, the circumference of the ear, the weight of the ear, the yield of seed, the productivity of the seed and the index vigor, growing speed, dry weight of normal sprouts and weight of 1000 seeds of seed. The best combination treatment for the production and quality of hybrid corn seeds is a combination treatment ((probyotic bacteria P24 + AcCKW5 (liquid 2) with Urea doses of $225 \mathrm{~kg} \mathrm{ha-}{ }^{1}, \mathrm{SP}-36$ $\left.150 \mathrm{~kg} \mathrm{ha-}{ }^{1}, \mathrm{KCl} 75 \mathrm{~kg} \mathrm{ha-}^{-1}\right)$.

Keywords: bacterial, nitrogen fixing, N, P, K fertilizer, phosphate solubilizing, seed production
\end{abstract}

\section{ABSTRAK}

Penelitian dilaksanakan Kebun Balai Besar Penelitian Tanaman Padi, Muara, Bogor dan Laboratorium Ilmu dan Teknologi Benih, Departemen Agronomi dan Hortikultura, Fakultas Pertanian, Institut Pertanian Bogor dari bulan November 2016 hingga Mei 2017 dengan rancangan RKLT satu faktor dan tiga ulangan. Faktor yang digunakan adalah kombinasi pupuk N, P, K dan bakteri probiotik yang terdiri dari 15 taraf perlakuan yaitu P1N1, P2N1, P3N1, P4N1, P5N1, P1N2, P2N2, P3N2, P4N2, P5N2, $\mathrm{P} 1 \mathrm{~N} 4, \mathrm{P} 2 \mathrm{~N} 4, \mathrm{P} 3 \mathrm{~N} 4, \mathrm{P} 4 \mathrm{~N} 4$ dan P5N4 dengan keterangan bahwa N1 = kontrol, $\mathrm{N} 2=75 \mathrm{~kg} \mathrm{ha}^{-1}$ Urea, $50 \mathrm{~kg}$ $\mathrm{ha}^{-1} \mathrm{Sp}-36,25 \mathrm{~kg} \mathrm{ha}^{-1} \mathrm{Kcl}$ dan $\mathrm{N} 4=225 \mathrm{~kg} \mathrm{ha}^{-1}, 150 \mathrm{~kg} \mathrm{ha}^{-1} \mathrm{Sp}-36,75 \mathrm{~kg} \mathrm{ha}^{-1} \mathrm{Kcl}$ serta $\mathrm{P} 1=$ kontrol, $\mathrm{P} 2=\mathrm{P} 24$ + AzL7, P3= P24 + AcCKW5, P4= P24 + AzL7 dan P5= P24 + AcCKB20. Bakteri P24 merupakan bakteri golongan Pseudomonas sp. sebagai pelarut fosfat, AzL7 adalah bakteri dari kelas Azotobacter, AcCKB20 dan AcCKW5 bakteri kelas Actinomycetes sp. sebagai penambat nitrogen. Hasil penelitian menunjukkan kombinasi pupuk $\mathrm{N}, \mathrm{P}, \mathrm{K}$ dan bakteri probiotik mempengaruhi tinggi tanaman dan jumlah daun 2, 4, 6 dan 8 MST serta mempengaruhi diameter batang 4, 6 dan 8 MST. Kombinasi pupuk N, P, K dan bakteri probiotik juga mempengaruhi jumlah tongkol panen, bobot tongkol kupasan, bobot pipilan kering, panjang tongkol, diameter tongkol, bobot tongkol, jumlah baris biji, bobot benih per tongkol, rendemen benih, produktivitas benih serta mempengaruhi indeks vigor, kecepatan tumbuh, bobot kering kecambah normal dan bobot 1000 butir benih. Perlakuan kombinasi terbaik untuk produksi dan mutu benih jagung hibrida adalah ((bakteri probiotik P24 + AcCKW5(cair 2) dengan dosis Urea $225 \mathrm{~kg} \mathrm{ha}^{-1}, \mathrm{SP}-36150 \mathrm{~kg} \mathrm{ha}^{-1}, \mathrm{KCl} 75 \mathrm{~kg} \mathrm{ha}^{-1}$ ).

Kata kunci : bakteri, pelarut fosfat, penambat nitrogen, poduksi benih, pupuk N, P, K 


\section{PENDAHULUAN}

Peningkatan produksi jagung dapat dilakukan melalui penggunaan benih hibrida bermutu. Varietas hibrida merupakan varietas unggul hasil pemuliaan tanaman yang terbukti mampu berproduksi $15 \%$ lebih baik dibandingkan varietas bersari bebas (Satimela et al., 2006). Dalam beberapa dekade terakhir, rata-rata hasil produksi benih jagung hibrida masih tergolong rendah, walaupun jika dibandingkan dengan varietas bersari bebas benih hibrida masih menempati posisi tertinggi dalam hal produksi. Namun, dengan rata-rata hasil benih jagung hibrida yang masih terbilang rendah menyebabkan harga benih hibrida F1 mahal. Dengan demikian, perlu adanya upaya yang dilakukan untuk meningkatkan pertumbuhan tetua betina sehingga produktivitas dan mutu benih jagung hibrida yang tinggi dapat dipenuhi.

Produksi jagung di Indonesia pada tahun 2013, 2014, dan 2015 adalah sebesar 18,51 juta ton, 19,01 juta ton dan 19,61 juta ton dengan produktivitas 4,84 ton per hektar, 4,95 ton per hektar dan 5,18 ton per hektar, serta luas panen 3,82 juta ha, 3,84 juta ha dan 3,79 juta ha (BPS, 2016). Berdasarkan data dari Badan Pusat Statistik tersebut dapat dilihat bahwa setiap tahunnya selalu dilaksanakan upaya-upaya peningkatan produksi dan produktivitas untuk mencapai target produksi pada tahun berikutnya. Salah satu upaya yang bisa dilakukan dalam peningkatan produktivitas jagung adalah dengan penggunaan benih bermutu. Menurut Wibowo (2013), usaha peningkatan mutu benih menjadi bagian penting dalam meningkatkan daya saing produk benih jagung hibrida. Namun hingga saat ini, sumberdaya dan kelembagaan perbenihan jagung dalam negeri belum merupakan produsen pertanian yang mumpuni dan berdaya saing handal (Baihaki, 2004).

Peningkatan mutu benih jagung hibrida menjadi bagian dari salah satu strategi peningkatan produktivitas jagung nasional (Purwanto, 2007). Dalam mendorong industri benih, penggunaan benih bermutu merupakan salah satu aspek penting karena dapat meningkatkan efisiensi biaya produksi serta meningkatkan produktivitas dan mutu benih (Hasanah, 2002). Produksi jagung yang cukup besar membutuhkan dukungan benih bermutu dalam jumlah yang cukup. Kombinasi benih unggul dengan varietas hibrida menjadi daya tarik bagi perusahaan benih swasta yang berperan memperbanyak dan menyebarluaskan benih bermutu sehingga jumlah yang cukup dapat terpenuhi. Selain itu penggunaan varietas hibrida dapat meningkatkan produktivitas (Edgerton, 2009).

\section{BAHAN DAN METODE}

Percobaan produksi benih dilaksanakan di Kebun Balai Besar Penelitian Tanaman Padi, Muara, Bogor. Proses pasca panen dilanjutkan di Kebun Percobaan Leuwikopo, IPB, Dramaga, Bogor. Pengujian mutu benih dilaksanakan di laboratorium Ilmu dan Teknologi Benih, Departemen Agronomi dan Hortikultura, Fakultas Pertanian, IPB dari bulan November 2016- Mei 2017. Bahan yang digunakan dalam percobaan produksi benih yaitu pupuk NPK, benih jagung hibrida dan bakteri probiotik. Pupuk NPK bersumber dari urea (sumber N) $300 \mathrm{~kg} \mathrm{ha}^{-1}$, SP36 (sumber $\mathrm{P}_{2} \mathrm{O}_{5}$ ) $200 \mathrm{~kg} \mathrm{ha}^{-1}$ dan $\mathrm{KCl}$ (Sumber $\left.\mathrm{K}_{2} \mathrm{O}\right) 100 \mathrm{~kg} \mathrm{ha}^{-1}$ berdasarkan dosis rekomendasi. Benih jagung yang digunakan diperoleh dari Balai Penelitian Serealia Maros, Sulawesi Selatan, yaitu benih jagung hibrida varietas Bima-3 yang terdiri dari Nei 9008 sebagai benih tetua betina dan $\mathrm{Mr}$ 14 sebagai benih tetua jantan. Bakteri probiotik yang digunakan berasal dari mikroba terpilih yang terdiri dari formulasi cair dan pasta dengan kandungan penambat $\mathrm{N}$ dan pelarut $\mathrm{P}$. Bahan yang digunakan dalam pengujian mutu benih yaitu benih hibrida hasil produksi di lapang, media kertas, plastik, label, aquades, alkohol dan amplop. Peralatan yang digunakan dalam produksi benih yaitu peralatan pertanian secara umum serta alat yang diperlukan saat pengamatan yaitu meteran, penggaris, jangka sorong, timbangan, alat tulis dan kamera digital. Peralatan untuk pengujian mutu benih menggunakan cawan porselen, oven, timbangan digital, ecogerminator dan desikator.

Faktor yang digunakan yaitu kombinasi pupuk N, P, K dan bakteri probiotik yang terdiri atas 15 taraf, yaitu :

P1N1 : Tanpa bakteri dan tanpa pemupukan N, P dan K (kontrol) P2N1 : P24 + AzL7(cair 1) dan tanpa pupuk $\mathrm{N}, \mathrm{P}, \mathrm{K}$

P3N1 : P24 + AcCKW5 (cair 2) dan tanpa pupuk N, P, K P4N1 : P24 + AzL7(pasta 1) dan tanpa pupuk N, P, K P5N1 : P24 + AcCKB20(pasta 2) dan tanpa pupuk $\mathrm{N}, \mathrm{P}, \mathrm{K}$

P1N2 : tanpa bakteri probiotik dan Urea $75 \mathrm{~kg}$ ha ${ }^{1}, \mathrm{SP}-3650 \mathrm{~kg} \mathrm{ha}^{-1}, \mathrm{KCl} 25 \mathrm{~kg} \mathrm{ha}^{-1}$

P2N2 : P24 + AzL7 (cair 1) dan Urea $75 \mathrm{~kg} \mathrm{ha}^{-1}$, SP-36 $50 \mathrm{~kg} \mathrm{ha}^{-1}, \mathrm{KCl} 25 \mathrm{~kg} \mathrm{ha}^{-1}$

P3N2 : P24 + AcCKW5(cair 2) dan Urea $75 \mathrm{~kg}$ ha $^{-1}$, SP-36 $50 \mathrm{~kg} \mathrm{ha}^{-1}, \mathrm{KCl} 25 \mathrm{~kg} \mathrm{ha}^{-1}$

P4N2 : P24 + AzL7(pasta 1) dan Urea $75 \mathrm{~kg} \mathrm{ha}^{-1}$, SP-36 $50 \mathrm{~kg} \mathrm{ha}^{-1}, \mathrm{KCl} 25 \mathrm{~kg} \mathrm{ha}^{-1}$

P5N2 : P24 + AcCKB20(pasta 2) dan Urea $75 \mathrm{~kg}$ $\mathrm{ha}^{-1}, \mathrm{SP}-3650 \mathrm{~kg} \mathrm{ha}^{-1}, \mathrm{KCl} 25 \mathrm{~kg} \mathrm{ha}^{-1}$ 
P1N4 : tanpa bakteri probiotik dan Urea $225 \mathrm{~kg}$ $\mathrm{ha}^{-1}$, SP-36 $150 \mathrm{~kg} \mathrm{ha}^{-1}, \mathrm{KCl} 75 \mathrm{~kg} \mathrm{ha}^{-1}$

P2N4 : P24 + AzL7(cair 1) dan Urea $225 \mathrm{~kg} \mathrm{ha}^{-1}$, SP-36 $150 \mathrm{~kg} \mathrm{ha}^{-1}, \mathrm{KCl} 75 \mathrm{~kg} \mathrm{ha}^{-1}$

P3N4 : P24 + AcCKW5(cair 2) dan Urea $225 \mathrm{~kg}$

$\mathrm{ha}^{-1}$, SP-36 $150 \mathrm{~kg} \mathrm{ha}^{-1}, \mathrm{KCl} 75 \mathrm{~kg} \mathrm{ha}^{-1}$

P4N4 : P24 + AzL7(pasta 1) dan Urea $225 \mathrm{~kg}$ ha

${ }^{1}, \mathrm{SP}-36150 \mathrm{~kg} \mathrm{ha}^{-1}, \mathrm{KCl} 75 \mathrm{~kg} \mathrm{ha}^{-1}$

P5N4 : P24 + AcCKB20(pasta 2) dan Urea $225 \mathrm{~kg}$ ha $^{-1}$, SP-36 $150 \mathrm{~kg} \mathrm{ha}^{-1}, \mathrm{KCl} 75 \mathrm{~kg} \mathrm{ha}^{-1}$

Bakteri probiotik formulasi cair dan pasta diaplikasikan ke perakaran tanaman dalam bentuk cair. Hal yang membedakan antara formulasi pasta dan cair adalah bentuk formulasi tersebut sebelum dilarutkan dan diaplikasikan ke perakaran tanaman. Setiap kombinasi perlakuan diulang sebanyak tiga kali, total perlakuan adalah 45 satuan percobaan. Ukuran petak setiap perlakuan pada kegiatan produksi benih jagung adalah $4,5 \mathrm{~m} \times 4,8 \mathrm{~m}$, jarak tanam $0,75 \mathrm{~m} \times 0,2$ $\mathrm{m}$, sehingga populasi setiap petak sebanyak 144 tanaman. Dalam setiap perlakuan terdapat 10 tanaman contoh, sehingga keseluruhan terdapat 450 tanaman contoh.

Prosedur percobaan antara lain mulai dari pengolahan tanah, penanaman dengan cara menanam tetua jantan secara 2 periode, yaitu 3 hari sebelum penanaman tetua betina dan bersamaan dengan penanaman tetua betina. Kemudian dilanjutkan dengan penyulaman pada 1 MST dan penjarangan satu minggu setelah penyulaman. Pemupukan NPK dilakukan pada 1 MST dengan dosis N1 (kontrol), N2 $25 \%$ (Urea $75 \mathrm{~kg} \mathrm{ha}^{-1} ;$ SP-36 $50 \mathrm{~kg} \mathrm{ha}^{-1} ; \mathrm{KCl} 25 \mathrm{~kg} \mathrm{ha}$ 1,) dan 75\% (Urea $225 \mathrm{~kg} \mathrm{ha}^{-1}$; SP-36 $150 \mathrm{~kg} \mathrm{ha}^{-1}$; $\mathrm{KCl} 75 \mathrm{~kg} \mathrm{ha}^{-1}$ ). Pupuk N diaplikasikan sebanyak dua kali yaitu pada saat tanaman jagung berumur 1 MST dan 6 MST, sedangkan pupuk P dan K diaplikasikan sebanyak satu kali yaitu pada saat tanaman berumur 1 MST. Pemupukan NPK berdasarkan perlakuan hanya dilakukan pada tetua betina, sedangkan tetua jantan dipupuk sesuai dosis rekomendasi. Bakteri probiotik diaplikasin saat sebelum tanam, 3
MST dan 6 MST terhadap tetua betina. Selanjutnya dilakukan penyiangan dan pembubunan, pengendalian hama dan penyakit, pencabutan bunga jantan, roguing, panen dan prosesing, pemipilan, dan pengujian mutu benih. Pengamatan dilakukan pada daya tumbuh tanaman, tinggi tanaman, jumlah daun, diameter batang, umur berbunga, umur panen, tinggi letak tongkol, panjang tongkol, diameter tongkol, bobot tongkol, bobot tongkol kupasan, bobot 1000 butir, bobot biji per tongkol, rendemen benih, jumlah baris biji, bobot pipilan kering serta terhadap mutu fisiologis yaitu potensi tumbuh maksimum (PTM), daya berkecambah (DB), indeks vigor (IV), kecepatan tumbuh $\left(\mathrm{Kc}_{\mathrm{T}}\right)$ dan bobot kering kecambah normal (BKKN).

\section{HASIL DAN PEMBAHASAN}

\section{Kondisi Umum Penelitian}

Penelitian dimulai November 2016 dengan penanaman tetua jantan tiga hari sebelum penanaman tetua betina dan bersamaan dengan penanaman tetua betina. Curah hujan pada November berdasarkan data BMKG stasiun klimatologi Bogor $279 \mathrm{~mm} /$ bulan dengan suhu rata-rata $26{ }^{\circ} \mathrm{C}$ dan kelembaban $87 \%$. Penelitian dilaksanakan dari bulan November 2016 hingga proses pengujian mutu benih April 2017. Dari kisaran bulan tersebut curah hujan tertinggi terjadi pada bulan Februari yaitu 647 $\mathrm{mm} /$ bulan, sedangkan terendah pada Desember sebesar $145 \mathrm{~mm} /$ bulan. Pada saat awal fase vegetatif hujan sering terjadi ketika sore, namun setelah fase generatif hujan terlihat mulai dari pagi. Pada masa vegetatif ditemui ulat tanah di sebagian tanaman jagung yang menyebabkan tanaman layu, mengering dan akhirnya rebah. namun penyerangan oleh ulat tanah tidak berlangsung lama dan tidak menyerang populasi yang tinggi sehingga daya tumbuh pertanaman masih tergolong cukup baik.

Tabel 1. Nilai rata-rata daya tumbuh benih berdasarkan perlakuan bakteri probiotik

\begin{tabular}{cc}
\hline Bakteri Probiotik & Daya Tumbuh (\%) \\
\hline P1 & 81,24 \\
P2 & 84,95 \\
P3 & 80,9 \\
P4 & 73,26 \\
P5 & 81,83 \\
\hline
\end{tabular}

Keterangan : P1= tanpa bakteri probiotik, P2= P24 + AzL7(cair 1), P3=P24 + AcCKW5(cair 2), P4= P24 + AzL7(pasta 1), P5= P24 + AcCKB20 (pasta 2)

\section{Daya Tumbuh Tanaman}

Daya tumbuh tanaman tetua betina jagung hibrida ini tergolong cukup baik, hal ini didukung kondisi lapang yang optimum. Di lapang, banyak faktor yang mempengaruhi daya tumbuh benih tersebut seperti kondisi tanah, 
cuaca, ketersediaan air dan faktor biotik lainnya. Daya tumbuh tanaman jagung yang cukup baik ini juga diduga oleh kondisi genetik dari benihnya sendiri, serta viabilitas dan vigor dari benih yang masih sangat baik. Menurut Justice dan Bass (2002), beberapa faktor yang mempengaruhi laju kemunduran benih diantaranya adalah jenis benih, berat dan bagian benih yang terluka, kelembaban dan suhu lingkungan di lapangan, penanganan panen serta kondisi penyimpanan benih.

\section{Tinggi Tanaman}

Hasil pengamatan tinggi tanaman menunjukkan bahwa perlakuan kombinasi pupuk $\mathrm{N}, \mathrm{P}, \mathrm{K}$ dan bakteri probiotik mempengaruhi tinggi tanaman pada 2 MST dan sangat mempengaruhi pada 4,6 dan 8 MST.

Tabel 2. Pengaruh perlakuan kombinasi pupuk N, P, K dan bakteri probiotik terhadap variabel tinggi tanaman

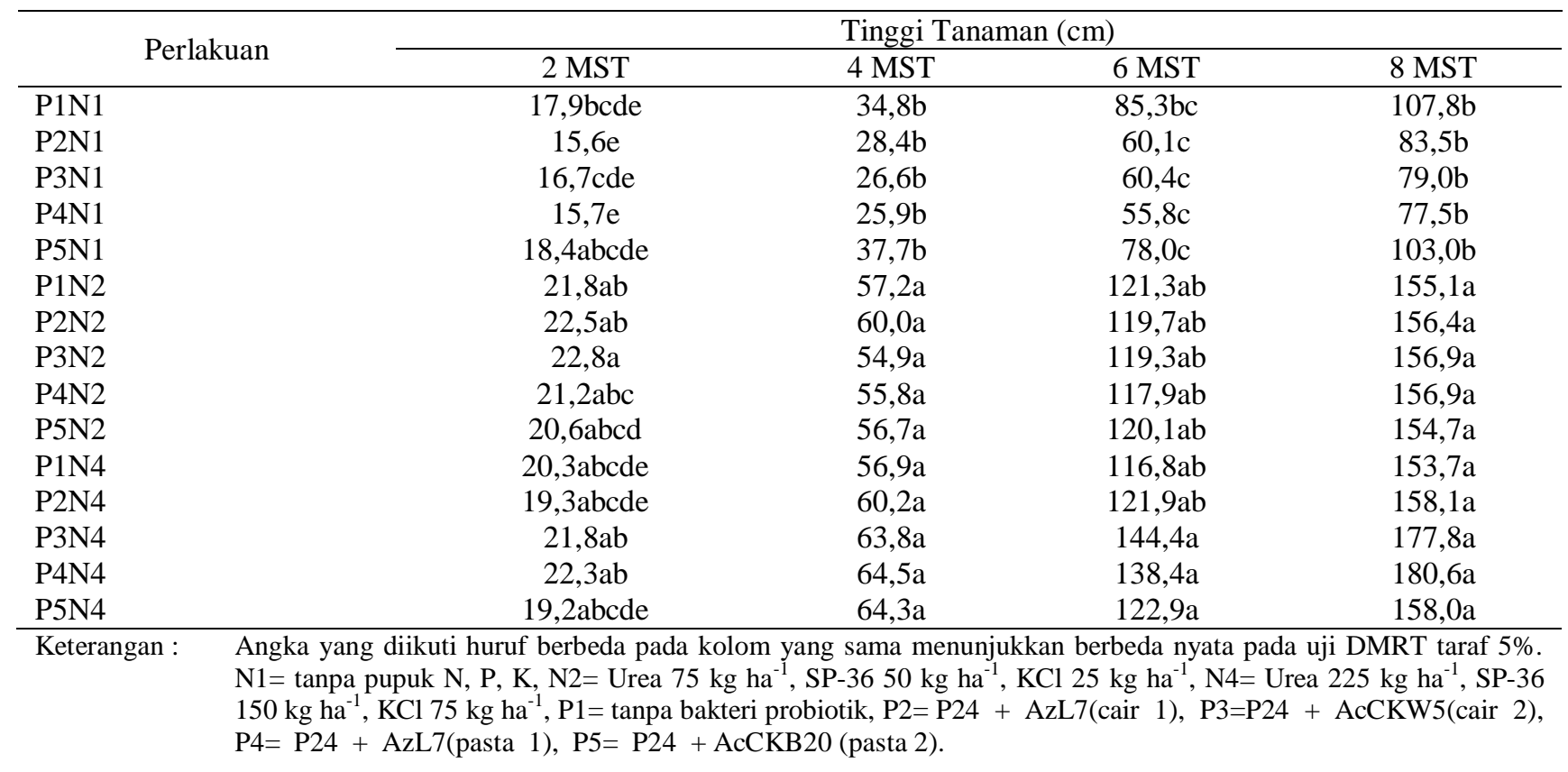

Berdasarkan pengamatan tinggi tanaman 2 MST, perlakuan kombinasi pupuk N, P, K dan bakteri tinggi tanaman tertinggi ditunjukkan oleh kombinasi perlakuan P3N2 yaitu 22,8 cm, namun tidak berbeda nyata dengan kombinasi perlakuan P1N2, P2N2, P3N4 dan P4N4. Pengamatan tinggi tanaman pada 4 MST hasil tertinggi ditunjukkan oleh kombinasi perlakuan P4N4 yaitu $64,5 \mathrm{~cm}$, namun tidak berbeda nyata dengan kombinasi perlakuan P1N2, P2N2, P3N2, P4N2, P5N2, P1N4, P2N4, P3N4 dan P5N4. Pengamatan tinggi tanaman pada 6 MST, hasil tertinggi diperoleh dari kombinasi perlakuan P3N4 yaitu $144,4 \mathrm{~cm}$ dan tidak berbeda nyata dengan kombinasi perlakuan P4N4 dan P5N4. Pengamatan tinggi tanaman 8 MST menunjukkan tinggi tanaman terbaik dari kombinasi perlakuan P5N2 yaitu 154,7 cm (mendekati sinkronisasi tinggi tetua jantan) dan tidak berbeda nyata dengan kombinasi perlakuan P1N2, P2N2, P3N2, P4N2, P1N4 dan P2N4. Hasil terendah tinggi tanaman pada 8 MST ditunjukkan oleh kombinasi perlakuan $\mathrm{P} 4 \mathrm{~N} 1$ yaitu $77,5 \mathrm{~cm}$ dan tidak berbeda nyata dengan kombinasi perlakuan $\mathrm{P} 1 \mathrm{~N} 1, \mathrm{P} 2 \mathrm{~N} 1, \mathrm{P} 3 \mathrm{~N} 1$ dan P5N1. Kombinasi perlakuan P4N4 terlihat memberikan tinggi tanaman yang paling tinggi pada 8 MST, namun tidak bisa dikatakan sebagai tinggi tanaman terbaik karena melebihi tinggi tanaman tetua jantan yang akan menyebabkan ketidaksinkronan saat penyerbukan terjadi.

Tinggi tanaman yang diharapkan dari tetua betina tanaman jagung hibrida Bima-3 ini adalah tinggi tanaman tetua betina yang tidak melebihi tinggi tanaman tetua jantan yaitu $170 \mathrm{~cm}$ (Lampiran 3), namun juga tidak mendekati 170 $\mathrm{cm}$. Hal tersebut berhubungan dengan sinkronisasi penyerbukan oleh kedua tetua. Berdasarkan data tinggi tanaman 8 MST (Tabel 2), tinggi tanaman yang menunjukkan hampir mendekati dengan tinggi tanaman tetua betina pada deskripsi varietas $(140 \mathrm{~cm})$ adalah kombinasi perlakuan P1N2, P2N2, P3N2, P4N2, $\mathrm{P} 5 \mathrm{~N} 2, \quad \mathrm{P} 1 \mathrm{~N} 4, \quad \mathrm{P} 2 \mathrm{~N} 4$ dan untuk kombinasi perlakuan P3N4, P4N4 serta P5N4 memiliki tinggi tanaman melebihi $170 \mathrm{~cm}$ (berdasarkan deskripsi varietas tetua jantan). 
Tabel 3. Pengaruh perlakuan kombinasi pupuk N, P, K dan bakteri probiotik terhadap variabel jumlah daun

\begin{tabular}{lcccc}
\hline \multirow{2}{*}{ Perlakuan } & \multicolumn{4}{c}{ Jumlah Daun } \\
\cline { 2 - 5 } & $2 \mathrm{MST}$ & $4 \mathrm{MST}$ & $6 \mathrm{MST}$ & $8 \mathrm{MST}$ \\
\hline P1N1 & $3,4 \mathrm{abcd}$ & $5,6 \mathrm{abc}$ & $7,1 \mathrm{a}$ & $7,2 \mathrm{~b}$ \\
P2N1 & $2,9 \mathrm{~cd}$ & $4,5 \mathrm{~d}$ & $5,7 \mathrm{~b}$ & $6,1 \mathrm{c}$ \\
P3N1 & $2,9 \mathrm{~cd}$ & $4,7 \mathrm{bcd}$ & $5,8 \mathrm{~b}$ & $6,0 \mathrm{c}$ \\
P4N1 & $2,9 \mathrm{~d}$ & $4,7 \mathrm{~cd}$ & $5,9 \mathrm{~b}$ & $6,0 \mathrm{c}$ \\
P5N1 & $3,5 \mathrm{abcd}$ & $5,5 \mathrm{abcd}$ & $7,1 \mathrm{ab}$ & $7,7 \mathrm{~b}$ \\
P1N2 & $3,8 \mathrm{ab}$ & $6,1 \mathrm{a}$ & $7,7 \mathrm{a}$ & $10,1 \mathrm{ab}$ \\
P2N2 & $4,2 \mathrm{a}$ & $5,9 \mathrm{ab}$ & $8,1 \mathrm{a}$ & $10,7 \mathrm{a}$ \\
P3N2 & $4,1 \mathrm{a}$ & $5,5 \mathrm{abcd}$ & $7,8 \mathrm{a}$ & $11,3 \mathrm{a}$ \\
P4N2 & $3,9 \mathrm{ab}$ & $5,7 \mathrm{abc}$ & $7,9 \mathrm{a}$ & $10,5 \mathrm{a}$ \\
P5N2 & $3,7 \mathrm{abcd}$ & $6,3 \mathrm{a}$ & $8,4 \mathrm{a}$ & $11,6 \mathrm{a}$ \\
P1N4 & $3,5 \mathrm{abcd}$ & $5,9 \mathrm{a}$ & $7,5 \mathrm{a}$ & $10,9 \mathrm{a}$ \\
P2N4 & $3,5 \mathrm{abcd}$ & $5,7 \mathrm{abc}$ & $7,5 \mathrm{a}$ & $10,5 \mathrm{a}$ \\
P3N4 & $3,8 \mathrm{abc}$ & $6,3 \mathrm{a}$ & $8,6 \mathrm{a}$ & $11,4 \mathrm{a}$ \\
P4N4 & $3,9 \mathrm{ab}$ & $6,2 \mathrm{a}$ & $8,2 \mathrm{a}$ & $10,6 \mathrm{a}$ \\
P5N4 & $3,2 \mathrm{bcd}$ & $5,9 \mathrm{a}$ & $8,1 \mathrm{a}$ & $11,3 \mathrm{a}$ \\
\hline KN
\end{tabular}

Keterangan : $\quad$ Angka yang diikuti huruf berbeda pada kolom yang sama menunjukkan berbeda nyata pada uji DMRT taraf 5\%. $\mathrm{N} 1=$ tanpa pupuk N, P, K, N2= Urea $75 \mathrm{~kg} \mathrm{ha}^{-1}, \mathrm{SP}-3650 \mathrm{~kg} \mathrm{ha}^{-1}, \mathrm{KCl} 25 \mathrm{~kg} \mathrm{ha}^{-1}, \mathrm{~N} 4=$ Urea $225 \mathrm{~kg} \mathrm{ha}^{-1}, \mathrm{SP}-36$ $150 \mathrm{~kg} \mathrm{ha}^{-1}, \mathrm{KCl} 75 \mathrm{~kg} \mathrm{ha}^{-1}, \mathrm{P} 1=$ tanpa bakteri probiotik, $\mathrm{P} 2=\mathrm{P} 24+$ AzL7 (cair 1), P3=P24 + AcCKW5 (cair 2), P4= P24 + AzL7(pasta 1), P5= P24 + AcCKB20 (pasta 2).

Pengamatan jumlah daun 2 MST menunjukkan jumlah daun terbanyak dari kombinasi perlakuan P2N2 yaitu 4,2 daun dan tidak berbeda nyata dengan perlakuan kombinasi P3N2 dan P4N4. Pada 4 MST, jumlah daun terbanyak ditunjukkan oleh kombinasi P5N2 dan P3N4 yaitu 6,3 daun tidak berbeda nyata dengan kombinasi perlakuan P1N2, P1N4, P4N4 dan P5N4. Jumlah daun terendah pada 4 MST ditunjukkan oleh kombinasi perlakuan P2N1 4,5 daun dan tidak berbeda nyata dengan kombinasi perlakuan P3N1 dan P4N1. Pada pengamatan 6 MST, jumlah daun terbanyak diperoleh dari kombinasi perlakuan P3N4 yaitu 8,6 daun dan tidak berbeda nyata dengan kombinasi perlakuan P1N2, P2N2, P3N2, P4N2, P5N2, P1N4, P2N4, P4N4 dan P5N4. Pada pengamatan 8 MST, jumlah daun terbanyak ditunjukkan oleh kombinasi perlakuan P5N2 yaitu 11,6 daun dan tidak berbeda nyata dengan kombinasi perlakuan P2N2, P3N2, P4N2, P1N4, P2N4, P3N4, P4N4 dan P5N4. Jumlah daun terendah pada 8 MST ditunjukkan oleh kombinasi perlakuan P3N1 dan P4N1 yaitu 6,0 daun dan tidak berbeda nyata dengan kombinasi perlakuan P2N1.

Tabel 4. Pengaruh perlakuan kombinasi pupuk N, P, K dan bakteri probiotik terhadap variabel diameter batang

\begin{tabular}{lcccc}
\hline \multirow{2}{*}{ Perlakuan } & \multicolumn{4}{c}{ Diameter Batang $(\mathrm{cm})$} \\
\cline { 2 - 5 } & $2 \mathrm{MST}$ & $4 \mathrm{MST}$ & $6 \mathrm{MST}$ & $8 \mathrm{MST}$ \\
\hline P1N1 & 0,4 & $0,8 \mathrm{c}$ & $1,5 \mathrm{cde}$ & $1,8 \mathrm{~b}$ \\
P2N1 & 0,3 & $0,7 \mathrm{c}$ & $1,3 \mathrm{e}$ & $1,7 \mathrm{~b}$ \\
P3N1 & 0,3 & $0,7 \mathrm{c}$ & $1,2 \mathrm{e}$ & $1,5 \mathrm{~b}$ \\
P4N1 & 0,3 & $0,6 \mathrm{c}$ & $1,3 \mathrm{e}$ & $1,5 \mathrm{~b}$ \\
P5N1 & 0,4 & $0,9 \mathrm{c}$ & $1,5 \mathrm{de}$ & $1,6 \mathrm{~b}$ \\
P1N2 & 0,4 & $1,7 \mathrm{ab}$ & $2,2 \mathrm{ab}$ & $2,4 \mathrm{a}$ \\
P2N2 & 0,4 & $1,7 \mathrm{ab}$ & $1,9 \mathrm{abcd}$ & $2,4 \mathrm{a}$ \\
P3N2 & 0,4 & $1,3 \mathrm{~b}$ & $1,8 \mathrm{bcd}$ & $2,4 \mathrm{a}$ \\
P4N2 & 0,4 & $1,6 \mathrm{ab}$ & $2,0 \mathrm{abcd}$ & $2,4 \mathrm{a}$ \\
P5N2 & 0,4 & $1,6 \mathrm{ab}$ & $2,2 \mathrm{a}$ & $2,9 \mathrm{a}$ \\
P1N4 & 0,4 & $1,7 \mathrm{ab}$ & $2,0 \mathrm{abc}$ & $2,5 \mathrm{a}$ \\
P2N4 & 0,5 & $1,7 \mathrm{ab}$ & $2,0 \mathrm{abcd}$ & $2,5 \mathrm{a}$ \\
P3N4 & 0,4 & $1,8 \mathrm{a}$ & $2,1 \mathrm{ab}$ & $2,6 \mathrm{a}$ \\
P4N4 & 0,4 & $1,9 \mathrm{a}$ & $2,3 \mathrm{a}$ & $2,8 \mathrm{a}$ \\
P5N4 & 0,4 & $1,6 \mathrm{ab}$ & $1,9 \mathrm{abcd}$ & $2,7 \mathrm{a}$ \\
\hline KN
\end{tabular}

Keterangan : $\quad$ Angka yang diikuti huruf berbeda pada kolom yang sama menunjukkan berbeda nyata pada uji DMRT taraf 5\%. $\mathrm{N} 1=$ tanpa pupuk N, P, K, N2= Urea $75 \mathrm{~kg} \mathrm{ha}^{-1}, \mathrm{SP}-3650 \mathrm{~kg} \mathrm{ha}^{-1}, \mathrm{KCl} 25 \mathrm{~kg} \mathrm{ha}^{-1}, \mathrm{~N} 4=$ Urea $225 \mathrm{~kg} \mathrm{ha}^{-1}, \mathrm{SP}-36$ $150 \mathrm{~kg} \mathrm{ha}^{-1}, \mathrm{KCl} 75 \mathrm{~kg} \mathrm{ha}^{-1}, \mathrm{P} 1=$ tanpa bakteri probiotik, $\mathrm{P} 2=\mathrm{P} 24+\mathrm{AzL} 7$ (cair 1), P3=P24 + AcCKW5 (cair 2), P4= P24 + AzL7(pasta 1), P5= P24 + AcCKB20 (pasta 2). 
Pengaruh dari perlakuan kombinasi pupuk N, P, K dan bakteri probiotik memperngaruhi diameter batang mulai dari 4 MST, sedangkan pada 2 MST tidak berpengaruh. Pengamatan diameter batang 4 MST menunjukkan hasil diameter batang tertinggi ditunjukkan oleh kombinasi perlakuan P4N4 yaitu $1,9 \mathrm{~cm}$ dan tidak berbeda nyata dengan kombinasi perlakuan P1N2, P2N2, P4N2, P5N2, P1N4, P2N4, P3N4 dan P5N4. Hasil diamater batang terendah pada 4 MST ditunjukkan oleh kombinasi perlakuan $\mathrm{P} 4 \mathrm{~N} 1$ yaitu $0,6 \mathrm{~cm}$ dan tidak berbeda nyata dengan kombinasi perlakuan P1N1, P2N1, P3N1 dan P5N1. Pada 6 MST diamater batang tertinggi ditunjukkan oleh kombinasi perlakuan P4N4 yaitu $2,3 \mathrm{~cm}$ dan tidak berbeda nyata dengan kombinasi perlakuan P1N2, P5N2 dan P3N4. Diameter batang terendah pada 6 MST ditunjukkan oleh kombinasi perlakuan P3N1 yaitu $1,2 \mathrm{~cm}$ dan tidak berbeda nyata dengan kombinasi perlakuan P1N1, P2N1, P4N1 dan P5N1. Pada pengamatan diameter batang 8 MST, hasil diameter batang tertinggi ditunjukkan oleh kombinasi perlakuan P5N2 yaitu 2,9 cm dan tidak berbeda nyata dengan kombinasi perlakuan P1N2, P2N2, P3N2, P4N2, P1N4, P2N4, P3N4, P4N4 dan P5N4, sedangkan diameter batang terendah ditunjukkan oleh kombinasi perlakuan $\mathrm{P} 3 \mathrm{~N} 1$ dan $\mathrm{P} 4 \mathrm{~N} 1$ yaitu $1,5 \mathrm{~cm}$ namun tidak berbeda nyata dengan kombinasi perlakuan P1N1, P2N1 dan P5N1.

Pengaruh Kombinasi Pupuk N, P, K dan Bakteri Probiotik terhadap Variabel Umur Berbunga Betina dan Umur Panen
Umur Berbunga Betina. Berdasarkan dosis pupuk $\mathrm{N}, \mathrm{P}, \mathrm{K}$ yang diaplikaskan, perlakuan yang dikombinasikan dengan pupuk N1 memiliki umur berbunga 69 HST, perlakuan yang dikombinasikan dengan pupuk N2 memiliki umur berbunga 64 HST dan perlakuan yang dikombinasikan dengan pupuk N4 memiliki umur berbunga 59 HST. Hal ini diduga karena perlakuan yang dikombinasikan dengan pupuk N4 memiliki unsur hara yang lebih tinggi dibandingkan perlakuan yang lain terutama fosfat, sehingga umur berbunga perlakuan N4 lebih cepat dibandingkan perlakuan N2 dan N1. Hardjowigeno (2010) menyatakan bahwa ketersediaan pupuk fosfat dapat mempengaruhi proses pembungaan dan pembentukan biji. Berdasarkan umur berbunga tetua jantan (56 HST sesuai deskripsi varietas pada lampiran 3), dapat dilihat bahwa perlakuan yang dikombinasikan dengan dosis pupuk N4 memiliki umur berbunga yang lebih sinkron dibandingkan dengan perlakuan lainnya, yaitu 59 HST.

Umur Panen. Pemanenan dilakuan ketika sudah terlihat kriteria panen pada pertanaman jagung. Kriteria panen adalah ketika pada tanaman telah terlihat lapisan hitam (black layer) antara tongkol dan biji, serta telah menguningnya batang, daun dan kelobot juga mengeringnya rambut. Tanaman jagung siap dipanen ketika telah berumur 103 HST. Umur siap panen atau sering disebut umur masak fisiologis pada penelitian ini tergolong hampir sesuai dengan umur panen pada deskripsi tanaman tetua betina (Nei 9008) (Lampiran 2) yaitu +100 HST.

Tabel 5. Pengaruh perlakuan kombinasi pupuk N, P, K dan bakteri probiotik terhadap jumlah tongkol panen, bobot tongkol kupasan dan bobot pipilan kering

\begin{tabular}{|c|c|c|c|}
\hline \multirow{2}{*}{ Perlakuan } & \multicolumn{3}{|c|}{ Variabel Pengamatan } \\
\hline & Jumlah Tongkol Panen & Bobot Tongkol Kupasan/petak (kg) & Bobot Pipilan Kering/petak (kg) \\
\hline P1N1 & $71,7 \mathrm{bcd}$ & $3,88 \mathrm{c}$ & $1,34 \mathrm{~d}$ \\
\hline P2N1 & $65,7 \mathrm{~cd}$ & $2,63 \mathrm{c}$ & $0,60 \mathrm{~d}$ \\
\hline P3N1 & $57,0 \mathrm{de}$ & $2,35 \mathrm{c}$ & $0,46 \mathrm{~d}$ \\
\hline P4N1 & $45,0 \mathrm{e}$ & $2,24 \mathrm{c}$ & $0,39 \mathrm{~d}$ \\
\hline P5N1 & $83,0 \mathrm{abc}$ & $3,74 \mathrm{c}$ & $1,32 \mathrm{~d}$ \\
\hline P1N2 & $91,3 \mathrm{ab}$ & $8,34 \mathrm{ab}$ & $3,29 \mathrm{abc}$ \\
\hline P3N2 & $86,3 \mathrm{abc}$ & $7,90 \mathrm{~b}$ & $3,14 \mathrm{bc}$ \\
\hline P4N2 & $88,3 a b$ & $7,17 \mathrm{~b}$ & $2,76 \mathrm{c}$ \\
\hline P5N2 & $81,3 \mathrm{abc}$ & $7,98 b$ & $3,06 \mathrm{bc}$ \\
\hline P1N4 & $87,0 \mathrm{abc}$ & $9,13 \mathrm{ab}$ & $3,29 \mathrm{abc}$ \\
\hline $\mathrm{P} 2 \mathrm{~N} 4$ & $91,7 \mathrm{ab}$ & $9,74 \mathrm{ab}$ & $4,11 \mathrm{abc}$ \\
\hline P3N4 & $94,0 \mathrm{a}$ & $11,63 a$ & $4,66 \mathrm{a}$ \\
\hline P4N4 & $87,0 \mathrm{abc}$ & $9,20 \mathrm{ab}$ & $4,26 a b$ \\
\hline
\end{tabular}

Keterangan : $\quad$ Angka yang diikuti huruf berbeda pada kolom yang sama menunjukkan berbeda nyata pada uji DMRT taraf 5\%. $\mathrm{N} 1=$ tanpa pupuk N, P, K, N2= Urea $75 \mathrm{~kg} \mathrm{ha}^{-1}, \mathrm{SP}-3650 \mathrm{~kg} \mathrm{ha}^{-1}, \mathrm{KCl} 25 \mathrm{~kg} \mathrm{ha}^{-1}, \mathrm{~N} 4=$ Urea $225 \mathrm{~kg} \mathrm{ha}^{-1}, \mathrm{SP}-36$ $150 \mathrm{~kg} \mathrm{ha}^{-1}, \mathrm{KCl} 75 \mathrm{~kg} \mathrm{ha}^{-1}, \mathrm{P} 1=$ tanpa bakteri probiotik, P2= P24 + AzL7(cair 1), P3=P24 + AcCKW5(cair 2), P4= P24 + AzL7(pasta 1), P5= P24 + AcCKB20 (pasta 2). 
Jumlah Tongkol Panen, Bobot Tongkol Kupasan dan Bobot Pipilan Kering per Petak

Pengaruh perlakuan kombinasi pupuk $\mathrm{N}, \mathrm{P}, \mathrm{K}$ dan bakteri probiotik (Tabel 5) menunjukkan pada pengamatan jumlah tongkol panen diperoleh jumlah tongkol terbanyak dari kombinasi perlakuan P3N4 yaitu 94 tongkol dan tidak berbeda nyata dengan kombinasi perlakuan P1N2, P2N4 dan P5N4, sedangkan jumlah tongkol paling sedikit ditunjukkan oleh kombinasi perlakuan $\mathrm{P} 4 \mathrm{~N} 1$ yaitu 45 tongkol. Pengaruh perlakuan kombinasi pupuk N, P, K dan bakteri probiotik terhadap bobot tongkol kupasan menunjukkan hasil bobot tongkol kupasan tertinggi diperoleh dari perlakuan kombinasi P3N4 yaitu 11,63 kg dan bobot tongkol kupasan terendah ditunjukkan oleh perlakuan kombinasi P4N1 yaitu 2,24 kg dan tidak berbeda nyata dengan kombinasi P1N1, P2N1, P3N1 dan P5N1.

Tabel 6. Pengaruh perlakuan kombinasi pupuk N, P, K dan bakteri probiotik terhadap variabel tongkol

\begin{tabular}{lcccccc}
\hline \multirow{2}{*}{ Perlakuan } & \multicolumn{5}{c}{ Variabel Pengamatan } \\
\cline { 2 - 7 } & TLT $(\mathrm{cm})$ & PT $(\mathrm{cm})$ & DT $(\mathrm{cm})$ & BT $(\mathrm{g})$ & JBB & BBT $(\mathrm{g})$ \\
\hline P1N1 & 47,4 & $9,6 \mathrm{~cd}$ & $2,9 \mathrm{bcd}$ & $49,4 \mathrm{~b}$ & $9,6 \mathrm{~cd}$ & $15,9 \mathrm{bcd}$ \\
P2N1 & 32,2 & $8,6 \mathrm{~d}$ & $2,5 \mathrm{de}$ & $36,3 \mathrm{~b}$ & $7,9 \mathrm{de}$ & $7,0 \mathrm{~d}$ \\
P3N1 & 31,8 & $8,4 \mathrm{~d}$ & $2,3 \mathrm{e}$ & $32,1 \mathrm{~b}$ & $7,6 \mathrm{de}$ & $8,9 \mathrm{~d}$ \\
P4N1 & 29,8 & $8,6 \mathrm{~d}$ & $2,2 \mathrm{e}$ & $34,1 \mathrm{~b}$ & $6,7 \mathrm{e}$ & $6,4 \mathrm{~d}$ \\
P5N1 & 41,8 & $9,4 \mathrm{~cd}$ & $2,9 \mathrm{~cd}$ & $48,0 \mathrm{~b}$ & $10,5 \mathrm{bc}$ & $13,0 \mathrm{~cd}$ \\
P1N2 & 44,3 & $11,0 \mathrm{bc}$ & $3,5 \mathrm{a}$ & $101,0 \mathrm{a}$ & $13,8 \mathrm{a}$ & $39,5 \mathrm{ab}$ \\
P2N2 & 48,9 & $11,5 \mathrm{ab}$ & $3,5 \mathrm{a}$ & $94,4 \mathrm{a}$ & $13,7 \mathrm{a}$ & $45,6 \mathrm{a}$ \\
P3N2 & 41 & $11,6 \mathrm{ab}$ & $3,4 \mathrm{ab}$ & $95,7 \mathrm{a}$ & $12,7 \mathrm{ab}$ & $41,2 \mathrm{a}$ \\
P4N2 & 41,1 & $11,8 \mathrm{ab}$ & $3,5 \mathrm{a}$ & $94,0 \mathrm{a}$ & $13,3 \mathrm{a}$ & $39,5 \mathrm{ab}$ \\
P5N2 & 32 & $11,7 \mathrm{ab}$ & $3,7 \mathrm{a}$ & $101,0 \mathrm{a}$ & $13,0 \mathrm{ab}$ & $36,2 \mathrm{abc}$ \\
P1N4 & 33,1 & $11,9 \mathrm{ab}$ & $3,3 \mathrm{abc}$ & $96,3 \mathrm{a}$ & $12,3 \mathrm{abc}$ & $39,5 \mathrm{ab}$ \\
P2N4 & 34,8 & $13,0 \mathrm{a}$ & $3,8 \mathrm{a}$ & $117,0 \mathrm{a}$ & $13,6 \mathrm{a}$ & $51,8 \mathrm{a}$ \\
P3N4 & 37,8 & $12,2 \mathrm{ab}$ & $3,7 \mathrm{a}$ & $110,2 \mathrm{a}$ & $13,6 \mathrm{a}$ & $55,5 \mathrm{a}$ \\
P4N4 & 36,5 & $11,6 \mathrm{ab}$ & $3,6 \mathrm{a}$ & $109,4 \mathrm{a}$ & $13,0 \mathrm{ab}$ & $48,0 \mathrm{a}$ \\
P5N4 & 34,1 & $11,8 \mathrm{ab}$ & $3,7 \mathrm{a}$ & $104,7 \mathrm{a}$ & $13,5 \mathrm{a}$ & $43,6 \mathrm{a}$ \\
\hline KNyyyyyyyyyy
\end{tabular}

Keterangan: $\quad$ Angka yang diikuti huruf berbeda pada kolom yang sama menunjukkan berbeda nyata pada uji DMRT taraf 5\%. $\mathrm{N} 1=$ tanpa pupuk N, P, K, N2= Urea $75 \mathrm{~kg} \mathrm{ha}^{-1}, \mathrm{SP}-3650 \mathrm{~kg} \mathrm{ha}^{-1}, \mathrm{KCl} 25 \mathrm{~kg} \mathrm{ha}^{-1}, \mathrm{~N} 4=$ Urea $225 \mathrm{~kg} \mathrm{ha}^{-1}, \mathrm{SP}-36$ $150 \mathrm{~kg} \mathrm{ha}^{-1}, \mathrm{KCl} 75 \mathrm{~kg} \mathrm{ha}^{-1}, \mathrm{P} 1=$ tanpa bakteri probiotik, P2= P24 + AzL7(cair 1), P3=P24 + AcCKW5(cair 2), $\mathrm{P} 4=\mathrm{P} 24+\mathrm{AzL} 7$ (pasta 1), P5= P24 + AcCKB20 (pasta 2). TLT=Tinggi Letak Tongkol, PT=Panjang Tongkol, DT=Diameter Tongkol, BT=Bobot Tongkol, JBB=Jumlah Baris Biji, BBT=Bobot Benih per Tongkol.

Pengamatan panjang tongkol memperlihatkan hasil panjang tongkol terpanjang diperoleh dari kombinasi perlakuan P2N4 yaitu 13,0 cm, sedangkan panjang tongkol terpendek ditunjukkan oleh kombinasi perlakuan P3N1 yaitu $8,4 \mathrm{~cm}$ dan tidak berbeda nyata dengan kombinasi perlakuan P2N1 dan P4N1. Pengamatan terhadap diameter tongkol, diperoleh hasil diameter tongkol terbesar dari kombinasi perlakuan P2N4 yaitu 3,8 $\mathrm{cm}$ dan tidak berbeda nyata dengan kombinasi P1N2, P2N2, P4N2, $\mathrm{P} 5 \mathrm{~N} 2, \mathrm{P} 3 \mathrm{~N} 4, \mathrm{P} 4 \mathrm{~N} 4$ dan $\mathrm{P} 5 \mathrm{~N} 4$, sedangkan diameter tonggkol terkecil ditunjukkan oleh kombinasi perlakuan $\mathrm{P} 4 \mathrm{~N} 1$ yaitu 2,2 cm dan tidak berbeda nyata dengan kombinasi perlakuan P2N1 dan P3N1. Pengaruh perlakuan kombinasi pupuk N, P, K dan bakteri probiotik terhadap pengamatan bobot tongkol menunjukkan bobot tongkol terbesar diperoleh dari kombinasi perlakuan P2N4 yaitu $117 \mathrm{~g}$ dan tidak berbeda nyata dengan kombinasi P1N2, P2N2, P3N2, P4N2, P5N2, P1N4, P3N4, P4N4 dan P5N4. Bobot tongkol terkecil ditunjukkan oleh kombinasi P3N1 yaitu 32,1 g dan tidak berbeda nyata dengan kombinasi p1N1, P2N1, P4N1 dan P5N1.

Pengaruh perlakuan kombinasi pupuk $\mathrm{N}$, $\mathrm{P}, \mathrm{K}$ dan bakteri probiotik terhadap jumlah baris biji diperoleh jumlah baris biji terbanyak dari kombinasi P1N2 yaitu 13,8 baris dan tidak berbeda nyata dengan kombinasi P2N2, P4N2, P2N4, P3N4 dan P5N4. Jumlah baris biji paing sedikit diperoleh dari kombinasi perlakuan P4N1 yaitu 6,7 baris dan tidak berbeda nyata dengan kombinasi perlakuan P2N1 dan P3N1. Pengamatan bobot benih per tongkol menunjukkan kombinasi perlakuan yang memperlihatkan bobot benih per tongkol terbesar adalah P3N4 yaitu 55,5 g dan tidak berbeda nyata dengan kombinasi perlakuan P2N2, P3N2, P2N4, $\mathrm{P} 4 \mathrm{~N} 4$ dan $\mathrm{P} 5 \mathrm{~N} 4$, sedangkan bobot benih per tongkol yang paling kecil ditunjukkan oleh kombinasi P4N1 yaitu 6,4 g dan tidak berbeda nyata dengan kombinasi perlakuan $\mathrm{P} 2 \mathrm{~N} 1$ dan P3N1. 
Tabel 7. Pengaruh perlakuan kombinasi pupuk N, P, K dan bakteri probiotik terhadap variabel rendemen dan produktivitas benih

\begin{tabular}{lcc}
\hline \multirow{2}{*}{ Perlakuan } & \multicolumn{2}{c}{ Variabel Pengamatan } \\
\cline { 2 - 3 } & Rendemen Benih $(\%)$ & Produktivitas Benih (ton ha-1) \\
\hline P1N1 & $27,73 \mathrm{~cd}$ & $0,62 \mathrm{~d}$ \\
P2N1 & $25,57 \mathrm{de}$ & $0,28 \mathrm{~d}$ \\
P3N1 & $19,58 \mathrm{de}$ & $0,21 \mathrm{~d}$ \\
P4N1 & $15,049 \mathrm{e}$ & $0,18 \mathrm{~d}$ \\
P5N1 & $31,19 \mathrm{bcd}$ & $0,61 \mathrm{~d}$ \\
P1N2 & $39,54 \mathrm{abc}$ & $1,52 \mathrm{abc}$ \\
P2N2 & $43,76 \mathrm{a}$ & $1,79 \mathrm{abc}$ \\
P3N2 & $38,77 \mathrm{abc}$ & $1,45 \mathrm{bc}$ \\
P4N2 & $37,38 \mathrm{abc}$ & $1,28 \mathrm{c}$ \\
P5N2 & $37,66 \mathrm{abc}$ & $1,41 \mathrm{bc}$ \\
P1N4 & $30,06 \mathrm{abc}$ & $1,52 \mathrm{abc}$ \\
P2N4 & $42,07 \mathrm{a}$ & $1,90 \mathrm{abc}$ \\
P3N4 & $40,57 \mathrm{ab}$ & $2,16 \mathrm{a}$ \\
P4N4 & $46,25 \mathrm{a}$ & $1,97 \mathrm{ab}$ \\
P5N4 & $44,28 \mathrm{a}$ & $2,08 \mathrm{ab}$ \\
\hline
\end{tabular}

Keterangan : $\quad$ Angka yang diikuti huruf berbeda pada kolom yang sama menunjukkan berbeda nyata pada uji DMRT taraf 5\%. $\mathrm{N} 1=$ tanpa pupuk N, P, K, N2= Urea $75 \mathrm{~kg} \mathrm{ha}^{-1}, \mathrm{SP}-3650 \mathrm{~kg} \mathrm{~h}^{-1}, \mathrm{KCl} 25 \mathrm{~kg} \mathrm{ha}^{-1}, \mathrm{~N} 4=$ Urea $225 \mathrm{~kg} \mathrm{ha}^{-1}, \mathrm{SP}-36$ $150 \mathrm{~kg} \mathrm{ha}^{-1}, \mathrm{KCl} 75 \mathrm{~kg} \mathrm{ha}^{-1}, \mathrm{P} 1=$ tanpa bakteri probiotik, $\mathrm{P} 2=\mathrm{P} 24+$ AzL7 (cair 1), P3=P24 + AcCKW5 (cair 2), P4= P24 + AzL7(pasta 1), P5= P24 + AcCKB20 (pasta 2).

\section{Rendemen Benih dan Produktivitas Benih}

Pengaruh perlakuan kombinasi pupuk N,

$\mathrm{P}, \mathrm{K}$ dan bakteri probiotik (Tabel 11) menunjukkan bahwa perlakuan kombinasi P4N4 menunjukkan rendemen benih tertinggi yaitu $46,25 \%$ dan tidak berbeda nyata dengan kombinasi perlakuan $\mathrm{P} 2 \mathrm{~N} 2, \mathrm{P} 2 \mathrm{~N} 4, \mathrm{P} 3 \mathrm{~N} 4$ dan P5N4. Rendemen benih terkecil ditunjukkan dari kombinasi P4N1 yaitu $15,04 \%$ dan tidak berbeda nyata dengan kombinasi perlakuan P2N1 dan P3N1. Pengamatan terhadap poduktivitas benih menunjukkan bahwa kombinasi perlakuan P3N4 memberikan hasil produktivitas tertinggi yaitu 2,16 ton $\mathrm{ha}^{-1}$, sedangkan produktivitas terendah ditunjukkan oleh kombinasi $\mathrm{P} 4 \mathrm{~N} 1$ yaitu 0,18 ton ha $^{-1}$ dan tidak berbeda nyata dengan kombinasi perlakuan P1N1, P2N1, P3N1 dan $\mathrm{P} 5 \mathrm{~N} 1$. Nilai rata-rata produktivitas terbaik yang dihasilkan dari pertanaman jagung ini tergolong lebih tinggi dari rata-rata produktivitas berdasarkan deksripsi varietas yaitu 1,60 ton per hektar. Nilai produktivitas yang cukup baik pada penelitian ini diduga rata-rata hampir $85 \%$ dari jumlah tongkol jagung memiliki barisan biji yang terisi penuh. Barisan tongkol yang hampir terisi penuh diduga karena umur berbunga tetua jantan dan betina di lapangan yang terjadi secara sinkron. Sinkronisasi pembungaan terhadap bungan jantan dan bunga betina berhasil diupayakan dengan melakuan penanaman galur tetua jantan pada dua periode yang berbeda, sehingga penyerbukan berlangsung sempurna yang berdampak pada tingginya jumlah tongkol terisi benih.
Sesuai yang telah dijelaskan sebelumnya, pada saat proses pengisian biji kondisi lingkungan juga mendukung untuk perbaikan pertumbuhan tanaman. Hal ini menyebabkan waktu berbunga galur tetua betina menjadi tepat dengan waktu pecahnya serbuk sari dari tanaman tetua jantan, sehingga tetua betina hampir terserbuki sepenuhnya oleh polen dari tanaman tetua jantan yang sudah pecah terlebih dahulu.

\section{Uji Mutu Fisiologis dan Bobot 1000 Butir Benih}

Hasil uji lanjut (Tabel 8)pengaruh perlakuan kombinasi pupuk $\mathrm{N}, \mathrm{P}, \mathrm{K}$ dan bakteri probiotik terhadap indeks vigor menunjukkan indeks vigor tertinggi oleh kombinasi perlakuan P4N2 yaitu 90,0\% dan tidak berbeda nyata dengan kombinasi perlakuan P1N2, P2N2, P3N2, P5N2, P1N4, P2N4, P3N4, P4N4 dan $\mathrm{P} 5 \mathrm{~N} 4$, sedangkan indeks vigor terendah diperoleh dari kombinasi perlakuan $\mathrm{P} 2 \mathrm{~N} 1$ yaitu $71,7 \%$ dan tidak berbeda nyata dengan kombinasi perlakuan P3N1 dan P4N1.

Pengamatan terhadap kecepatan tumbuh diperoleh bahwa kombinasi P2N2, P5N2 dan P3N4 menunjukkan kecepatan tumbuh tertinggi dengan nilai yang sama yaitu 25,5\% dan tidak berbeda nyata dengan kombinasi perlakuan P5N1. Nilai kecepatan tumbuh terendah diperoleh dari kombinasi perlakuan P4N1 yaitu $20,1 \%$.

Pengamatan terhadap bobot kering kecambah normal menunjukkan nilai bobot kering kecambah normal tertinggi diperoleh dari kombinasi perlakuan P1N4 yaitu 0,073 g 
dan tidak berbeda nyata dengan kombinasi perlakuan P2N2, P2N4, P3N4 dan P5N4, sedangkan nilai bobot kering kecambah normal terkecil ditunjukkan oleh kombinasi perlakuan P2N1 dan P4N1 yaitu dengan nilai 0,047 g.

Pengaruh perlakuan kombinasi pupuk N, $\mathrm{P}, \mathrm{K}$ dan bakteri probiotik terhadap bobot 1000 butir benih menunjukkan hasil bobot 1000 butir benih tertinggi diperoleh dari kombinasi perlakuan P5N4 yaitu 227,1 g dan bobot 1000 butir benih terendah ditunjukkan oleh kombinasi perlakuan P4N1 yaitu 153,7 g dan tidak berbeda nyata dengan kombinasi perlakuan $\mathrm{P} 2 \mathrm{~N} 1$ dan P3N1.

Nilai daya berkecambah dan potensi tumbuh maksimum (Tabel 8) secara umum menunjukkan bahwa seluruh taraf kombinasi perlakuan termasuk kontrol memberikan persentase daya berkecambah dan potensi tumbuh maksimum yang tinggi yaitu diatas $90 \%$. Hal ini menunjukkan bahwa benih yang dihasilkan sudah memiliki mutu yang tinggi. Variabel pengamatan potensi tumbuh maksimum (PTM) dan daya berkecambah (DB) merupakan tolak ukur dari viabilitas suatu lot benih, sedangkan variabel pengamatan kecepatan tumbuh (KcT) yang mengindikasikan kepada tolok ukur vigor kekuatan tumbuh benih. Hasil pengujian ini menyatakan nilai PTM dan DB yang tinggi menandakan bahwa benih yang dihasilkan memiliki viabilitas yang tinggi, serta nilai kecepatan tumbuh (KcT) yang cukup baik menunjukkan bahwa benih memiliki vigor yang tinggi ketika di tanam dilapang.

Tabel 8. Pengaruh perlakuan kombinasi pupuk N, P, K dan bakteri probiotik terhadap variabel pengamatan mutu, fisiologis dan bobot 1000 butir benih

\begin{tabular}{lcccccc}
\hline \multirow{2}{*}{ Perlakuan } & \multicolumn{5}{c}{ Variabel } \\
\cline { 2 - 6 } & DB $(\%)$ & IV $(\%)$ & PTM $(\%)$ & KcT $(\%)$ & BKKN $(\mathrm{g})$ & Bobot 1000 butir $(\mathrm{g})$ \\
\hline P1N1 & 94 & $81,0 \mathrm{ab}$ & 99 & $23,8 \mathrm{ab}$ & $0,053 \mathrm{~cd}$ & $170,9 \mathrm{efg}$ \\
P2N1 & 93,3 & $71,7 \mathrm{~b}$ & 99,3 & $24,1 \mathrm{ab}$ & $0,047 \mathrm{~d}$ & $155,2 \mathrm{~g}$ \\
P3N1 & 91 & $74,7 \mathrm{~b}$ & 100 & $22,6 \mathrm{bc}$ & $0,06 \mathrm{abcd}$ & $157,1 \mathrm{~g}$ \\
P4N1 & 89,3 & $74,0 \mathrm{~b}$ & 96 & $20,1 \mathrm{c}$ & $0,047 \mathrm{~d}$ & $153,7 \mathrm{~g}$ \\
P5N1 & 94 & $78,3 \mathrm{ab}$ & 99,3 & $25,4 \mathrm{a}$ & $0,053 \mathrm{~cd}$ & $169,3 \mathrm{fg}$ \\
P1N2 & 99,3 & $86,3 \mathrm{a}$ & 100 & $24,4 \mathrm{ab}$ & $0,057 \mathrm{bcd}$ & $193,0 \mathrm{cdef}$ \\
P2N2 & 98,3 & $85,7 \mathrm{a}$ & 99,7 & $25,5 \mathrm{a}$ & $0,07 \mathrm{ab}$ & $212,4 \mathrm{abcd}$ \\
P3N2 & 97,7 & $85,0 \mathrm{a}$ & 100 & $24,5 \mathrm{ab}$ & $0,063 \mathrm{abc}$ & $197,7 \mathrm{bcde}$ \\
P4N2 & 98,3 & $90,0 \mathrm{a}$ & 100 & $25,2 \mathrm{ab}$ & $0,063 \mathrm{abc}$ & $188,3 \mathrm{def}$ \\
P5N2 & 97,3 & $86,7 \mathrm{a}$ & 99,7 & $25,5 \mathrm{a}$ & $0,067 \mathrm{abc}$ & $206,4 \mathrm{abcd}$ \\
P1N4 & 97,3 & $85,3 \mathrm{a}$ & 99,7 & $25,0 \mathrm{ab}$ & $0,073 \mathrm{a}$ & $219,3 \mathrm{abc}$ \\
P2N4 & 98 & $86,7 \mathrm{a}$ & 99,7 & $24,7 \mathrm{ab}$ & $0,070 \mathrm{ab}$ & $224,9 \mathrm{ab}$ \\
P3N4 & 97 & $85,0 \mathrm{a}$ & 99,7 & $25,5 \mathrm{a}$ & $0,070 \mathrm{ab}$ & $220,5 \mathrm{abc}$ \\
P4N4 & 97 & $84,0 \mathrm{a}$ & 99,3 & $24,8 \mathrm{ab}$ & $0,067 \mathrm{abc}$ & $220,2 \mathrm{abc}$ \\
P5N4 & 98,7 & $87,0 \mathrm{a}$ & 99 & $24,7 \mathrm{ab}$ & $0,070 \mathrm{ab}$ & $227,1 \mathrm{a}$ \\
\hline
\end{tabular}

Keterangan: $\quad$ Angka yang diikuti huruf berbeda pada kolom yang sama menunjukkan berbeda nyata pada uji DMRT taraf 5\%. $\mathrm{N} 1=$ tanpa pupuk N, P, K, N2= Urea $75 \mathrm{~kg} \mathrm{ha}^{-1}, \mathrm{SP}-3650 \mathrm{~kg} \mathrm{ha}^{-1}, \mathrm{KCl} 25 \mathrm{~kg} \mathrm{ha}^{-1}, \mathrm{~N} 4=$ Urea $225 \mathrm{~kg} \mathrm{ha}^{-1}, \mathrm{SP}-36$ $150 \mathrm{~kg} \mathrm{ha}^{-1}, \mathrm{KCl} 75 \mathrm{~kg} \mathrm{ha}^{-1}, \mathrm{P} 1=$ tanpa bakteri probiotik, P2= P24 + AzL7(cair 1), P3=P24 + AcCKW5(cair 2), P4= P24 + AzL7(pasta 1), P5= P24 + AcCKB20 (pasta 2).

\section{KESIMPULAN}

Hasil penelitian menunjukkan bahwa kombinasi pupuk $\mathrm{N}, \mathrm{P}, \mathrm{K}$ dan bakteri probiotik mempengaruhi tinggi tanaman dan jumlah daun 2, 4, 6 dan 8 MST serta mempengaruhi diameter batang 4, 6 dan 8 MST. Kombinasi pupuk N, P, K dan bakteri probiotik juga mempengaruhi jumlah tongkol panen, bobot tongkol kupasan, bobot pipilan kering, panjang tongkol, diameter tongkol, bobot tongkol, jumlah baris biji, bobot benih per tongkol, rendemen benih, produktivitas benih serta mempengaruhi indeks vigor, kecepatan tumbuh, bobot kering kecambah normal dan bobot 1000 butir benih. Perlakuan kombinasi terbaik yang direkomendasikan untuk produksi dan mutu benih jagung hibrida adalah kombinasi perlakuan P3N4 ((bakteri probiotik P24 + AcCKW5(cair 2) dengan dosis Urea $225 \mathrm{~kg} \mathrm{ha}^{-1}$, SP-36 $150 \mathrm{~kg} \mathrm{ha}^{-1}$, $\mathrm{KCl} 75 \mathrm{~kg} \mathrm{ha}^{-1}$ ). Pada pengamatan umur berbunga betina, perlakuan yang dikombinasikan dengan dosis N4 (Urea $225 \mathrm{~kg} \mathrm{ha}^{-1}$, SP-36 $150 \mathrm{~kg} \mathrm{ha}^{-1}$, $\mathrm{KCl} 75 \mathrm{~kg} \mathrm{ha}^{-1}$ ) menunjukkan umur berbunga betina yang lebih sinkron dengan umur berbunga tetua jantan.

\section{DAFTAR PUSTAKA}

Edgerton, M.D. 2009. Increasing crop productivity to meet global needs for feed, food, and fuel. Plant Physiol.149:7-13. 
Fadhly, A.F., S. Saenong, R. Arief, F. Tabri, S. Saenong, F. Koes 2010. Laporan Akhir Program Insentif Riset Terapan. Perakitan Teknologi Produksi Benih Jagung Hibrida Berumur Sedang (90100 Hari, Hasil Benih F1>2 T/Ha). Maros (ID): Pusat Penelitian dan Pengembangan Tanaman Pangan. Badan Penelitian dan Pengembangan Pertanian. Balai Penelitian Tanaman Serealia.

Hardjowigeno, S. 2010. Ilmu Tanah. Akademika Pressindo, Jakarta.

Hasanah, M. 2002. Peran mutu fisiologik benih dan pengembangan industri benih tanaman industri. J Litbang Pertanian 21(3):84-91.

Holt, J., N. Krieg, P. Sneath, J. Staley, S. Williams. 1994. Bergey's Manual of Determinative Bacteriology. ninth ed. Williams and Wilkins, .Baltimore.

Kraiser, T., D.E. Gras, A.G. Gutierrez, B. Gonzalez, R.A. Gutierrez. 2011. A holistic view of nitrogen acquisition in plants. J. Experimental Botany. 62(4): 1455-1466.
Mejaya, M.J., M. Azrai, R.N. Iriany. 2007. Pembentukan Varietas Unggul Jagung Bersari Bebas. Balai Penelitian Tanaman Serealia. Maros (ID). 19 hal.

Purwanto, S. 2007. Perkembangan produksi dan kebijakan dalam penigkatan produksi jagung. Di dalam:Jagung: Teknik Produksi dan Pengembangan. Direktorat Budi Daya Serealia, Direktorat Jenderal Tanaman Pangan(ID). hlm 456461.

Setimela, P.S., X. Mhike X, J.F. MacRobert, D. Muungani. 2006. Maize Hybrids and Open-Pollinated Varieties: Seed Production Strategies. In: Strategies for 27 Strengthening and Scaling up Community-based Seed Production. Setimela PS and Kosina P (eds). Mexico DF (US): CIMMYT FAO.

Sutoro, Y. S., Iskandar. 1998. Budidaya Tanaman Jagung. Hal. 49-66. Dalam Subandi, M. S. dan Widjono A. (Eds). Jagung. Badan Penelitian dan Perkembangan Pertanian. Bogor. 